\title{
The Extent Use of Contemporary Management Accounting Practices and Its Effect on Operational Performance of Industrial Corporations in Jordan
}

\author{
Naser Yousef Alzoubi \\ Accounting Department, Irbid National University, PO box 2600, Irbid 21110, Jordan \\ E-mail: naseryz@yahoo.com
}

Received: Dec. 18, 2017 Accepted: Feb. 21, 2018 Published: June 1, 2018

doi:10.5296/ajfa.v10i1.12270 URL: https://doi.org/10.5296/ajfa.v10i1.12270

\begin{abstract}
The purpose and aims of this study is to illustrate the extent use of contemporary management accounting practices MAPs in the Jordanian industrial corporations listed on Amman Stock Exchange ASE, and an attempt to find out the most common practice used. A field study conducted by using a questionnaire distributed to accountants working in 25 different industrial corporations, a total of $\mathbf{7 5}$ questionnaires distributed, $\mathbf{5 2}$ were valid for analysis purposes. The financial data related to the operational performance were collected for the periods 2013-2016. The study used arithmetic mean and standard deviation to describe the study sample and determine degree of implementation of contemporary MAPs.Multiple regression analysis used to detect the effect of MAPs on each indicator of operational performance.

Results of the study showed a moderate use of contemporary MAPs, such as Target costing, Kaizen costing and Just-in-time manufacturing, moreover a least used practices were Activity base costing and Balance scorecard, and analysis revealed a different effect of applied contemporary MAPs on operational performance indicators, an effects on inventory turnover rate is observed, and no statistically effect on operational ratio, receivables turnover and total assets turnover. Worthwhile, the researcher proposed a number of proposals and recommendations, emphasis in reconsideration of application mechanism of contemporary MAPs applied in the corporations, and activate the role of various contemporary MAPs used as an information system, which could assess the corporate managers and decision-makers serving the management's objectives in the industrial corporations.
\end{abstract}

Keywords: Management accounting practices, Operational performance, Industrial corporations 


\section{Introduction}

Since the middle of the last century, there has been increasing interest in studying the effect of industrial applications resulted from technological and economic developments in manufacturing environment, leading to an increased competition among industrial companies in all fields, and resulting a rapid changes in design and developing the concept of accounting information system in general, and information systems of managerial accounting and cost accounting in particular, thus, companies can maintain their competitive position and market share, therefore the use of new and improved of contemporary MAPs plays an important role in creating competitive advantages for industrial companies within the market in which they operate. MAPs provide decision makers with means to maintain competitive advantage (Waldron,2007).

Furthermore, companies seek to provide the best and most accurate, most appropriate and flexible information in order to provide suitable and valuable information needed for the management of industrial companies to address the problems related to manufacturing and production.

However, significant changes in the business environment and emergence of modern manufacturing environment have reflected the effectiveness of modern accounting information systems and the effectiveness of managerial accounting information systems and cost accounting. MAPs provide information to managers and help them to find solution of problems and assess performance.( Heitger et al., 2008)

The development in industrial sector has been accompanied by the emergence of modern philosophies and concepts of manufacturing methods and the orientation of many industries to improve and develop their business programs. The emphasis was emerged toward the need to develop MAPs, techniques and methods in accordance with these changes in order to achieve the company's economic objectives in general and its financial objectives in particular. Moreover, generating of profit ensures growth and continuity of companies which are subject to the efficiency and effectiveness of their operational performance.

\section{Problem Statement}

The concepts and methods of management accounting have evolved through the development of its tools to assist corporate management and decision makers to perform their tasks of planning, monitoring and evaluating performance, As well as helps management to balance between cost reduction and product quality, Which will result an increase in company's sales and reduce costs at the same time. This justifies the belief that it will raise the capacity of the operational performance of those corporations which are applying different MAPs. The study problem can be summarized as follows:

2.1 To what extent the application of contemporary MAPs in Jordanian industrial corporations are utilized?

The practices are presented as independent variables:

Activity Based Costing (ABC), Balance scorecard (BSC), Just-in-time manufacturing (JIT) Target costing (TC),Kaizen Costing (KC). 
2.2 What is the effect of using different contemporary MAPs on operational performance of Jordanian industrial corporations?

The operational indicators presented as dependent variables are:

Total Assets, Turnover, Receivables Turnover, Inventory Turnover and Operating Ratio.

\section{Objectives of the Study}

This study attempt to investigate the relationship between two important variables, the contemporary MAPs applied and the operational performance of the corporation, which carry important indicators for management, investors and owners.

The objective of this study is to measure the extent use of contemporary MAPs and its effect on operational performance of Jordanian industrial corporations through the following steps:

3.1 Measuring the degree of application contemporary MAPs in Jordanian industrial corporations listed on Amman Stock Exchange.

3.2 Use appropriate indicators to measure operational performance of corporations represented in the study sample.

3.3 Determine to what extent the utilization of different contemporary MAPs effects the operational performance of the Jordanian industrial corporations.

\section{Background and Previous Studies}

\subsection{Management Accounting Practices MAPs}

The application of MAPs and tools aims to provide the necessary data and information for management to carry out planning, control, performance evaluation and management decisions, leading to the optimal utilization of available economic resources through the application of various MAPs. Management accounting information service several major roles in organization, it enhances decision making, guides strategy development and evaluate existing strategies (Kaplan \& Atkinson,1998).Management accounting is a process of measuring, analyzing, preparation and interpretation of financial information used by management for planning, evaluation and oversight within the organization to ensure the appropriate use and accountability of its resources(Moscove\&Wright,1990; Bhattacharyya \& Dearder,1996).

Managerial accounting is concerned with providing information to managers and users within the organization directly and it provides the organization with the necessary basic information through the preparation of various types of reports, some of them related to performance and comparison with what is planned, and the other frequently and periodically, analytical reports to investigate specific problems facing the organization (Garrison, et al., 2012). Managerial accounting is the process of identifying, measuring, analyzing, interpreting and communicating information in pursuit of an organization's goals, it's an integrated part of the management process, and are important strategic partner in an organization's management team (Hilton, 2002).

The scientific and industrial progress has led to fundamental and continuous changes in the performance of business, as well as the intensification of competition between industrial and economic establishments. It requires the economic establishments to apply modern concepts and MAPs to meet the new challenges and competition imposed in markets, this requires management to intensify its work to achieve better productivity and achieve the best possible 
performance and work to increase profits and improve the level of services and products manufacturing. The researcher believes that MAPs are applied in the Jordanian industrial corporations either fully or partially, therefore the study will focus on the following contemporary MAPs:

- Activity Based Costing (ABC)

-Target costing (TC)

- Kaizen Costing (KC)

- Balance scorecard (BSC)

- Just-in-time manufacturing (JIT)

\section{i. Activity Based Costing (ABC)}

The $\mathrm{ABC}$ concept is an integrated and comprehensive framework that tries to identify activities that consume resources and then trace the source of the costs associated with those activities resources, whereas the total cost of these activities is obtained. The next stage is to allocate the (Activity Costs) to the products by specifying the cost driver for each activity by calculating the average cost of that (Cost Drive) and using it as a basis on how much of a particular activity is needed to produce a product. $(\mathrm{ABC})$ as a strategic tool for the company to obtain more accurate cost and information operations, products, services and customers, whereas contributes making many important decisions, including pricing decisions, marketing and design of the product or service, and resource utilization decisions ( Cooper \& Kaplan, 1988 )( Argyris \& Kaplan,1994). It's a cost calculation method designed to provide managers with the cost information needed to make strategic decisions and other decisions that are likely to affect the company's production capacity as well as fixed costs as well as variable costs, which is used as a support tool to the company's cost system rather than as a substitute (Garrison, et al., 2012).

\section{ii. Target Costing (TC)}

Most target costing definitions are related to what happens in competitive markets where cost reduction is a requirement and a necessary element to achieve profitability. Cost reduction is necessary in all phases of product design and development which will be reflected in cost reduction for the entire product lifecycle. Target costing is a cost management tool that planners use during product and process design to drive improvement efforts aimed at reducing the product's future manufacturing costs, it's a tool that promote an facilitate communication among the members of the cross-functional team that is responsible for product design, it begins with price,quality and punctuality requirements defined by customers (Kaplan \& Atkinson,1998). Target costing involves seven key principles: Price- led costing, that is subtracting the target profit margin from this target price yields the target cost. Focus on the customer, management must listen to the company's customers. Focus on product design, engineers must design a product from the ground up so that it can be produced at its target cost. Focus in process design, every aspect of the production process must be examined to make sure that the product is produced as efficiently as possible. Cross-functional team, manufacturing a product at or below its target cost requires the involvement of people from many different functions in an organization. Life -cycle cost, in specifying a product's target cost, analyzing must be careful to incorporate all of product's life-cycle costs. Value-chain orientation, efforts are made to eliminate non-value added costs to bring the projected cost down (Ansari \& Bell 
2010). Target costing is an important tool to enhance management's awareness of costs and therefore focus on profit margin, which strengthens the competitive position of the company (Bahar, 2012).Target Cost Management provides analytical methods and tools to develop new products and supporting strategic objectives such as market share and profit of the company, Target costing can be a critical tool for management as it seeks to strategic ally manage the company's cost and profit,by ensuring that product are designed so that they can be produced at a low enough cost to be priced competitively (Hilton, 2002).

iii. Kaizen Costing (KC)

Kaizen Costing is a continuous development system, which is consistent with the target cost system in terms of the objectives of reducing costs and product development. It achieves this through continuous control of the production process at all stages of manufacturing to ensure that they are in the correct manner. The concept of continuous improvement is a performance objective that seeks to maximize the benefit of the consumer by reducing costs. Therefore, it relates mainly to the operational aspects of the company under the concept of continuous improvement. It aims to eliminate all causes of waste, reduce waste of production or administrative activities, and thus obtain sophisticated and low-cost products ( Howell, 1994).Kaizen costing focuses the organization's attention on things that managers or operators of an existing system can do to reduce costs, and the cost reduction efforts driven by Kaizen costing is incremental improvement to the current production process or product design, these improvements take the form of developing improved process, improving machine performance to reduce waste, and increasing employee training and motivation to encourage employees to identify and implement the incremental daily changes that can improve cost and quality performance. Organization attack continuous improvement in different ways and the Kaizen costing system will reflect the cost reduction strategy (Hilton, 2002).Continuous improvement is a process of gradual change that focuses on performing existing tasks in a more effective way, and constantly working to make some improvements, even if they are simple. Continuous improvement continuous journey, aiming to identify road signs, set goals, solve problems, develop skills and training to reach the best results(Dodds,1992).

\section{iv. Balanced Scorecard (BSC)}

The BSC technique was developed by Kaplan and Norton $(1992,1996)$ in order to combine financial control measures with non-financial control measures. The BSC was developed to communicate the multiple, linked objectives that companies must archive to compete on the basis of capabilities and innovation, not just tangible physical assets, organized in four perspectives: financial, customer, internal business process, and learning and growth (Kaplan \& Atkinson,1998). It is a strategic tool that relies on four perspectives to assess the organization's performance rather than focusing solely on the financial perspective, moreover creating an overview of the organization, furthermore the traditional measures that focus on the financial perspective are not sufficient for the contemporary business environment and attention to a broader set of standards that relate to quality, market share, customer satisfaction and employees can lead to greater insight of the organization's position. BSC is a model that presents a variety of ways to manage the organization to earn satisfactory returns through strategic decision making and taking into consideration the effects reflected on financial measurement, customers, internal business process, and learning. It's a Performance analysis 
and measurement based on the analysis of financial and non-financial performance measures. This card is an evaluation tool for a short and long term performance. The BSC contributes to providing a clear vision of the organization about its current status and future, it is an approach based on the premise that measurement is a precondition for strategic management (Horngren, et al., 2009). It's a tool consisting of a set of performance metrics derived from the Organization's strategy that enables the organization to translate its strategy through four sets of performance measures labor, internal processes, growth and development, and financial measures, (Garrison, et al., 2012).

\section{v. Just-in-time manufacturing (JIT)}

The aim of JIT manufacturing is based on the idea of not purchasing or producing a particular item as long as it does not the company receives a request from the customers, meaning that the purchase or production of a particular item is made immediately after the company receives an order from its customers. The philosophy of this system is based on that the revenue of the company is not the production or purchase or accumulation of goods in warehouses, but revenue occurs when conduct the sales process. It is natural that producers have to predict the future demand for their products in order to facilitate the production process to meet this demand on the one hand, and to employ the highly skilled workers on the other, in order to reduce production costs for maximum profits (Garrison, et al., 2012). Toyota was the first to adopt JIT manufacturing in the fifties of the last century, it has achieved the a remarkable results in increasing production capacity by reducing waste (Kaneko \& Nojiri, 2008). JIT is a philosophy that eliminates waste in all activities and processes involved in a particular production process within the company, leading to development and reduction of costs (Cobb, 1992). JIT is a system that works to reduce the levels of inventory of raw materials, units under production and inventory of producing units, thus improving the efficiency and quality of production and improving profitability.JIT manufacturing rely on a limited number of suppliers ready to supply small quantities in several batches per day required by the company on time without delay (Garrison, et al., 2012). JIT inventory and production management system, all inventories are kept very low, since finished goods inventories are minimal. In JIT production process, setups would be quicker and more frequent and production runs would be smaller and fewer inspection would be required due to total quality control philosophy that often accompanies JIT (Hilton(2002).

\subsection{The concept of performance}

The concept of performance evaluation is a comprehensive objective specifying the strategies, policies and procedures to examine the results of the activities and effectiveness and compare plans and specific rules in order to detect positive and negative deviations, and to ensure the efficient management of economic resources. Performance is known as a reflection of the organization ability to achieve its goals (Eccles, 1991), which is also a reflection of how to use the organization's financial, human resources and exploitation of resources to enable the managements to achieve objectives (Miller \& Bromiley, 1990). (Robins \& Wiersema, 1995) defined it as the organization's ability to achieve its long-term goals.

\subsection{Previous Studies}

Many studies and researches conducted about MAPs in order to investigate the applying of 
deferent management accounting approaches or the contemporary management accounting philosophies.

Waldron (2007) he made a comparative analysis of MAPs used by New Zealand companies, and mainly focused on showing the levels of application of MAPs in many countries in order to propose international standards for comparison purposes. The study concluded that the traditional management accounting tools are still widely used in most companies, and the modern methods of management accounting are less used. The study showed the difference of applying of MAPs by New Zealand companies mainly depend to the size of each company.

Simon, et al (2005) the study sought to measure and evaluate the different MAPs in Slovenian companies and compare the application of different MAPs as well as in different industrial sectors. The study concluded that the most common method of managerial accounting used by Slovenian companies is the capital budgets, followed by evaluation of competitors' performance, The method of assessing customers as assets, the client's profitability and cost of product life cycle, there is a difference in application of MAPs in different sectors, Capital budgets, competitors' performance assessment, competitor status control, pricing strategy and customer profitability analysis. The most widely used sector of MAPs where industrial sector, transportation and logistics, and the less utilization of MAPs are the construction general services companies.

Topor, et al (2011) the study explained and clarified the role of MAPs in providing the necessary information to managers within institutions to provide more ability and make better decisions by studying the case of the Romanian manufacturing industries. The study relied on the descriptive approach. The most important results were that the management accounting information is very important within the entities and emphasis that managers of these companies need the management accounting information in time for decision making. The study recommended that there is a need to improve utilization of MAPs, and emphasized the need to increase implementation of MAPs in Romanian manufacturing industries.

Al-Khalil (2012) the research aimed to demonstrate the application of modern MAPs in the Jordanian industrial companies and to identify the difficulties encountered in use of these methods. Results showed that the Jordanian industrial companies apply modern managerial accounting techniques, and indicate that industrial companies are implementing to a high degree the activity based costing. Conclusions emphasized the necessity of continue applying and enhancing utilization of these techniques and managers should select the appropriate technique to utilize the best of it. The study out lined the importance of conducting a feasibility study for each new method to be applied and a comparison between costs incurred by this application and benefits the company could gain of it. Also, researcher believes that there is a need to ensure the existence of an active administration structure which is the main and most important reason for the success of applying the modern MAPs, moreover, the necessity to train employees before the adoption of MAPs in order to benefit from these techniques ideally. Ashfaq, et al (2014) the study examined the level of using MAPs in service sector in Pakistan represented by Insurance, Banking, telecommunication and computer service companies. Investigation made to assess the use of MAPs in companies which are moving from growth to maturity stage. The study concluded that traditional MAPs are still used more than advanced methods. Conclusion reveals that both traditional and advanced MAPs are important for 
service sector and companies can get more benefits.

Andrei (2017) believes that an implementing of management accounting systems should take into account the mentality and culture that people involved in practicing the MAPs. He also pointed out that management behavior can affect the practices of managerial accounting, and applying of management accounting systems suffering due to the lack of professionals in the field and inadequate managerial vision at national level in Romania. He concluded that organizations need more stimulation to adopt management accounting systems and call the professional and academic accountants to be more active in identifying and assessing the new management accounting systems, as well as more empirical studies and field research are necessary to assess the aspects related to the implications of human nature in implementation processes shouldn't be ignored.

Cuzdriorean (2017) the objective of the study was to examines the MAPs adopted by the Romanian small and medium size enterprises. The researcher investigated thirty seven enterprises to determine which tools are being used by Romanian small and medium size enterprises, moreover to identify reasons why some specific MAPs are not being used. The study pointed out that a large number of enterprises use a few number of MAPs such as budgeting systems for controlling costs and planning cash flows, and a very little use of modern MAPs such as benchmarking and performance reporting based on financial and non-financial indicators. The researcher attributed the finding to the fact that the main reasons for not adopting certain traditional and modern MAPs were the lack of management commitment or high costs of implementation and that have led to a conclusion that Romanian small and medium size enterprises heavily rely on traditional MAPs rather than modern MAPs. Ahmad (2017) the study aimed to explore the extent use and implementation of MAPs among Malaysian small and medium size enterprises in manufacturing sector and focused in finding a relationship between MAPs and performance. The study sought to measure the level of applying MAPs and found a difference between traditional and sophisticated approach. Furthermore, sophisticated MAPs are frequently utilized by larger enterprises and effect of size is an important factor leads to adoption of MAPs. The study indicated that a certain MAPs are found to have significant relationships with performance and findings have emphasized the importance and need of MAPs in Malaysian organizations. The most utilized practices were, costing system and performance measurement system, budgeting system, decision support system and strategic management accounting, but the study revealed that an employment of new management accounting skills, such as activity based costing and strategic management accounting and other modern techniques, are less utilized than basic techniques, and the traditional MAPs are still dominant. Finding were concluded that using of MAPs have significant roles for increasing the level of efficiency and performance of small and medium size enterprises, and suggests to improve awareness and understanding the effect and the relationship between MAPs and performance.

\section{Study Hypotheses}

Based on the above presentation, and in order to answer the main question of the study "What is the effect of using different contemporary MAPs on operational performance of Jordanian industrial corporations" The null hypothesis summarized as follows: 


\section{Macrothink}

Asian Journal of Finance \& Accounting

ISSN 1946-052X

2018, Vol. 10, No. 1

H01: There is no statistically significant effect of applied contemporary MAPs on the rate of Total Assets turnover in the Jordanian industrial corporations.

H02: There is no statistically significant effect of applied contemporary MAPs on the rate of Receivables turnover in the Jordanian industrial corporations.

H03: There is no statistically significant effect of applied contemporary MAPs on the rate of Inventory turnover in the Jordanian industrial corporations.

H04: There is no statistically significant effect of applied contemporary MAPs on Operating ratio in the Jordanian industrial corporations.

\section{Methodology}

\subsection{Research instrument}

To achieve the study objectives and testing hypotheses, an analytical descriptive approach used, and relies on reviewing previous related studies to the topic addressed in the current study. The researcher also used a field study approach, which is based on collecting field data using a questionnaire distributed to a group of accountants working in different Jordanian industrial corporations, moreover, the data regarding dependent variables, which is Total Assets turnover, Receivable turnover, Inventory turnover and Operating ratio are collected from official published financial reports.

\subsection{The Study Population and Sample}

The study population consists of all listed industrial corporations in Amman Stock Exchange (ASE). The questionnaires were distributed to a group of accountants working in deferent Jordanian industrial corporations, a sample of the study was selected using random sampling procedures, 75 questionnaires were distributed, 52 questionnaires received representing a response rate of $(80 \%)$, which are valid for analysis of the total questionnaires distributed and suitable for the process of statistical analysis. Cronbach Alpha was used to measure the reliability of study tool and the internal consistency of all questionnaire paragraphs, the Cronbach Alpha was (88.3\%), which is sufficient, high and acceptable for the purposes of testing the reliability of study tool.

The study sample includes the Jordanian industrial corporations listed in (ASE).Published financial reports during the period of the study were 68 corporations according to (ASE) for the periods 2013-2016.Data collected as shown in (Table 1) below a random sample of 25 corporations, which represent (36\%) of total number of industrial corporations listed in (ASE). 
Table 1. The study Sample of industrial corporations

\begin{tabular}{lll}
\hline Category & Frequency & Percent \\
\hline chemical industries & 3 & 12.00 \\
electrical industries & 2 & 8.00 \\
engineering and construction & 3 & 12.00 \\
food and beverages & 5 & 20.00 \\
mining and extraction industries & 5 & 20.00 \\
pharmaceutical and medical industries & 4 & 16.00 \\
textiles, leathers and clothing & 2 & 8.00 \\
tobacco and cigarettes & 1 & 4.00 \\
$\quad$ Total & 25 & 100.00 \\
\hline
\end{tabular}

\subsection{Statistical Analysis and Hypothesis Testing}

The Statistical Package for Social Sciences program has been used (Statistical Package for Social Sciences (SPSS) to analysis the data collected. Descriptive statistics methods used in order to make a comparison among the responses of the study sample, the means value used to measure the central tendency and standard deviation to measure the dispersion of the answers around the averages for the various statements questionnaire.

\subsection{Description of the Study Sample Responses}

Tables $(2,3,4,5$ and 6$)$ illustrate a description of the study sample answers using the mean and standard deviation for each answer of statements in the questionnaire, as well as the order of each statement according to the arithmetic mean. Moreover, the following tables show the perceptions of respondents concerning the utilization of contemporary MAPs.

To what extent the application of contemporary MAPs in Jordanian industrial corporations are utilized. These practices are (ABC),(TC),(KC),(BSC) and. (JIT).

Table 2. Means and standard deviation of Activity Based Costing (ABC) domain, total means $(\mathrm{n}=52)$

No Domain Mean $\quad \begin{aligned} & \text { Standard. } \\ & \text { Deviation }\end{aligned}$ Rank $\begin{aligned} & \text { Agreement } \\ & \text { Degree }\end{aligned}$


1 The cost for each activity is determined

1.86

0.78

8

Low

2 Administration has the ability to separate direct and indirect costs.

1.74

0.78

9

Low

Multiple upload rates are used for activity costs taking account causal relationship between costs and the

Low activities that cause the cost.

Ability to identify activities that each product consumes.

$\begin{array}{llll}2.38 & 0.83 & 3 & \text { Medium }\end{array}$

Activities are divided into activities

5 which add value to the product and

2.16

0.81

6 Low

activities that do not add .

Administration has the ability to

6 determine the exact number of activities

3.69

1.14

$1 \quad$ High

that cause the cost of each activity.

$7 \quad$ Indirect costs are allocated to activities.

$2.24 \quad 0.86$

$4 \quad$ Low

Production divided into sub-activities to

8 facilitate the determinant costs of each

$2.17 \quad 0.86$

5 Low

product.

Reduction of activities that do not add

9 value to the product such as (storage and handling costs).

$\begin{array}{llll}2.67 & 1.03 & 2 & \text { Medium }\end{array}$

Total Means

0.34

Low

Table (2) shows that the highest means reached (3.69) out of (5) for item (6) "Administration has the ability to determine the exact number of activities that cause the cost of each activity" by high agreement degree, then for item (9) "Reduction of activities that do not add value to the product such as to the product such as (storage and handling costs)." (means 2.67) by medium agreement degree, then for item (4) "Ability to identify activities that each product consumes" (means 2.38) by medium agreement degree, and the lowest means was (1.74) for item (2) "Administration has the ability to separate direct and indirect costs" by low agreement degree. The total means for "Activity Based Costing" reached (2.32) by low agreement degree. 
Table 3. Means and standard deviation for Target Costing (TC) domain, total means $(n=52)$

\begin{tabular}{|c|c|c|c|c|c|}
\hline No & Domain & Mean & $\begin{array}{l}\text { Standard. } \\
\text { Deviation }\end{array}$ & Rank & $\begin{array}{l}\text { Agreement } \\
\text { Degree }\end{array}$ \\
\hline 1 & $\begin{array}{l}\text { Competitive products are studied, } \\
\text { analyzed and compared with the } \\
\text { company's products. }\end{array}$ & 3.21 & 0.89 & 6 & Medium \\
\hline 2 & $\begin{array}{l}\text { The total cost of the product is } \\
\text { determined before starting the } \\
\text { production process. }\end{array}$ & 3.76 & 1.00 & 1 & High \\
\hline 3 & $\begin{array}{l}\text { The profit margin of the product is } \\
\text { determined prior production. }\end{array}$ & 3.40 & 0.86 & 3 & Medium \\
\hline 4 & $\begin{array}{l}\text { The selling price of the product is } \\
\text { determined based on market studies } \\
\text { before starting the production process. }\end{array}$ & 3.00 & 0.75 & 8 & Medium \\
\hline 5 & $\begin{array}{l}\text { The profit margin of the product is } \\
\text { determined based on the product's status } \\
\text { among its competitors. }\end{array}$ & 3.31 & 0.78 & 4 & Medium \\
\hline 6 & $\begin{array}{l}\text { Administration seeks to reduce product } \\
\text { costs at an early stage of production. }\end{array}$ & 3.21 & 0.83 & 6 & Medium \\
\hline 7 & $\begin{array}{l}\text { The cost of the product is taken into } \\
\text { account during the design and planning } \\
\text { phase. }\end{array}$ & 3.64 & 0.85 & 2 & Medium \\
\hline 8 & $\begin{array}{l}\text { Administration is working on reducing } \\
\text { cost through measures leading to cost } \\
\text { reduction during production. }\end{array}$ & 3.22 & 0.56 & 5 & Medium \\
\hline 9 & $\begin{array}{l}\text { The profit margin of the product is } \\
\text { determined based on the expected sales } \\
\text { volume of the production. }\end{array}$ & 2.28 & 0.74 & 9 & Low \\
\hline \multicolumn{2}{|c|}{ Total Means } & 3.22 & 0.40 & - & Medium \\
\hline
\end{tabular}

Table (3) shows that the highest means reached (3.76) out of (5) for item (2) "The total cost of the product is determined before starting the production process" by high agreement degree, 
then for item (7) "The cost of the product is taken into account during the design and planning phase." (means 3.64) by high agreement degree, then for item (3) "The profit margin of the product is determined prior production" (means 3.40 ) by medium agreement degree, and the lowest means was (2.28) for item (9) "The profit margin of the product is determined based on the expected sales volume of the product" by low agreement degree. The total means for "Target Costing" reached (3.22) by medium agreement degree.

Table 4. Means and standard deviation for Kaizen Costing (KC) domain, total means $(\mathrm{n}=52)$

No Domain Mean $\quad \begin{aligned} & \text { Standard. } \\ & \text { Deviation }\end{aligned}$ Rank $\begin{aligned} & \text { Agreement } \\ & \text { Degree }\end{aligned}$

Administration analyzes the competing

1 products and compares them with $2.28 \quad 1.02 \quad 10 \quad$ Low company's products.

Administration works and study all

2 possible ways of reducing the cost of $3.66 \quad 0.98 \quad 8 \quad$ Medium manufacturing during every stage.

3 Administration is concerned with product features and specifications.

$\begin{array}{llll}3.84 & 1.04 & 5 & \text { High }\end{array}$

4 Administration seeks to eliminate waste of resources.

$\begin{array}{llll}3.95 & 0.78 & 3 & \text { High }\end{array}$

Inspections and control of products are

5 carried out continuously to ensure quality.

$\begin{array}{llll}3.78 & 0.80 & 6 & \text { High }\end{array}$

Administration adopts continuous

6 improvement system at every stage of product life cycle.

$\begin{array}{llll}4.14 & 0.83 & 2 & \text { High }\end{array}$

Administration works to increase the

7 efficiency of the employees to increase their productivity.

Administration adopts continuous

8 improvement system at every stage since product design until the sales stage of it.

$\begin{array}{llll}4.17 & 0.86 & 1 & \text { High }\end{array}$

9 Reducing costs is done by reducing the

3.76

0.82

$7 \quad$ High 
number of defective and damaged units.

Administration adopts a continuous improvement approach.

High

Total Means

High

Table (4) shows that the highest means reached (4.17) out of (5) for item (8) "Administration adopts continuous improvement system at every stage since product design until the sales stage of it" by high agreement degree, then for item (6) "Administration adopts continuous improvement system at every stage of product life cycle" (means 4.14) by high agreement degree, then for item (4) "Administration seeks to eliminate waste of resources" (means 3.95) by high agreement degree, and the lowest means was (2.28) for item (1) "Administration analyzes the competing products and compares them with company's products" by low agreement degree. The total means for "Kaizen Costing" reached (3.68) by high agreement degree.

Table 5. Means and standard deviation for Balanced Scorecard (BSC) domain, total means $(\mathrm{n}=52)$

No Domain Mean $\quad \begin{aligned} & \text { Standard. } \\ & \text { Deviation }\end{aligned}$ Rank $\begin{aligned} & \text { Agreement } \\ & \text { Degree }\end{aligned}$

Application of the Balanced Scorecard

1 System helps in evaluating the performance of the company contributes

$\begin{array}{llll}3.69 & 0.94 & 1 & \text { High }\end{array}$

to the development of strategic plans.

Application of a balanced scorecard

2 system helps in evaluating the performance of the company and strengthening the control system.

Application of a balanced scorecard

3 system helps in evaluating the performance of the company and

$\begin{array}{llll}1.84 & 0.83 & 9 & \text { Low }\end{array}$
development of tactical plans.

Administration monitors the

4 performance and to what extent $2.33 \quad 0.85 \quad 4 \quad$ Low objectives are achieved.

5 Administration sets standards for $\begin{array}{llllll}1.95 & 0.83 & 8 & \text { Low }\end{array}$ 
financial performance and profitability.

Administration sets standards to

6 measure the customer's satisfaction regarding the company's products.

The Company's performance evaluation

7 system includes different financial measures.

$\begin{array}{llll}2.40 & 0.70 & 3 & \text { Medium }\end{array}$

Application of a balanced scorecard helps in evaluating the performance of the company and helps in measuring the $\begin{array}{llll}2.12 & 0.96 & 5 & \text { Low }\end{array}$ performance of non-financial aspects.

The expected results of implementation

9 exceed the cost of implementing the balanced scorecard system.

$\begin{array}{llll}1.98 & 0.81 & 6 & \text { Low }\end{array}$

(a)

\section{Total Means}

Low

Table (5) shows that the highest means reached (3.69) out of (5) for item (1) "Application of the Balanced Scorecard System helps in evaluating the performance of the company contributes to the development of strategic plans" by high agreement degree, then for item (2) "Application of a balanced scorecard system helps in evaluating the performance of the company and strengthening the control system" (means 2.43) by medium agreement degree, then for item (7) "The Company's performance evaluation system includes different financial measures" (means 2.40) by medium agreement degree, and the lowest means was (1.84) for item (3) "Application of a balanced scorecard system helps in evaluating the performance of the company and development of tactical plans" by low agreement degree. The total means for "Balanced Scorecard" reached (2.30) by low agreement degree.

Table 6. Means and standard deviation for Just-in-Time Manufacturing (JIT) domain, total means $(n=52)$

No Domain Mean $\quad \begin{aligned} & \text { Standard. } \\ & \text { Deviation }\end{aligned}$ Rank $\begin{aligned} & \text { Agreement } \\ & \text { Degree }\end{aligned}$

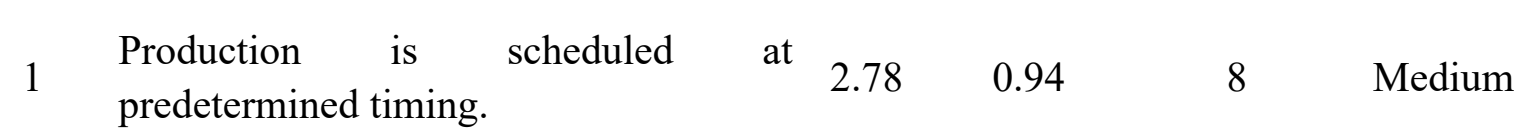

The company has a collaborative team

2 responsible for carrying out tasks and

$\begin{array}{llll}2.93 & 0.95 & 5 & \text { Medium }\end{array}$
coordinating their activities to maintain 
a smooth flow of operations.

3 Reductions of stock quantities of raw materials are taking into consideration.

0.92

3

Medium

Machines are classified as

4 manufacturing cells based on production processes.

Work is done to shorten and minimize activities that do not add value to the product such as (Storage and handling 3.88 1.08 2 High costs).

The time utilization in production

6 process is optimized to minimize waste in time.

$\begin{array}{llll}2.98 & 0.93 & 4 & \text { Medium }\end{array}$

The machines or service offices are

7 arranged in such a way to optimize the utilization of workspace.

Machines or services work are arranged in a manner that does not permit the

8 existence of unfinished production or unfinished services in production $\begin{array}{llll}2.91 & 0.94 & 6 & \text { Medium }\end{array}$ process.

The company relies on a certain number 9 of reliable suppliers, whom committed to deliver raw materials and production $\begin{array}{llll}2.16 & 1.15 & 9 & \text { Low }\end{array}$ requirements on time.

Table (6) shows that the highest means reached (3.98) out of (5) for item (6) "The time utilization in production is optimized to minimize waste in time." by high agreement degree, then for item (4) "Machines are classified as manufacturing cells based on production processes" (means 3.88) by high agreement degree, then for item (3) "Reduction of stock quantities of raw materials are taking into consideration." (means 3.00) by medium agreement degree, and the lowest means was (2.16) for item (9) Company relies on a certain number of reliable suppliers, whom committed to deliver raw materials and production requirements on time" by low agreement degree. The total means for "Just-in-Time Manufacturing" reached 
(3.05) by medium agreement degree.

Table (7) shows the aggregate level of application of each MAPs used in the Jordanian industrial corporations.

Table 7. Means and standard deviation for each domain and total means $(n=52)$

\begin{tabular}{|c|c|c|c|c|c|}
\hline No & Domain & Mean & $\begin{array}{l}\text { Standard. } \\
\text { Deviation }\end{array}$ & Rank & $\begin{array}{l}\text { Agreement } \\
\text { Degree }\end{array}$ \\
\hline 1 & Target Costing & 3.22 & 0.40 & 2 & Medium \\
\hline 2 & Just-in-Time Manufacturing & 3.05 & 0.42 & 3 & Medium \\
\hline 3 & Activity Based Costing & 2.32 & 0.34 & 4 & Low \\
\hline 4 & Balanced Scorecard & 2.30 & 0.34 & 5 & Low \\
\hline 5 & Kaizen Costing & 3.68 & 0.34 & 1 & High \\
\hline \multicolumn{2}{|c|}{ Total Means } & 2.93 & 0.16 & - & Medium \\
\hline
\end{tabular}

Table (7) shows that the highest means reached (3.68) for the domain (5) "Kaizen Costing" by high agreement degree, then for domain (1) "Target Costing" (means 3.22) by medium agreement degree, then for domain (2) "Just in Time Manufacturing" (means 3.05) by medium agreement degree, and the lowest means were for domain (3) "Activity Based Costing" (means 2.32) and (2.30) for domain (4) "Balanced Scorecard" by low agreement degree.

The total means of "study tool" reached (2.93) by medium agreement degree. According to the results shown in the previous table, the aggregate level of application of MAPs in the industrial corporations is medium.

\subsection{Hypothesis Testing}

For testing hypotheses. Multiple Regressions analysis was used to measure the effect of contemporary MAPs on operational performance (Total assets Turnover, Receivable Turnover, Inventory Turnover and Operating Ratio) extracted from the financial reports of the study sample consisting of 25 Jordanian industrial corporations.Table (8) shows the aggregate calculation for the dependent variables (operational performance).

Table 8. Means and standard deviation of operational performance in the Jordanian industrial corporations. $(n=25)$

\section{No Variable}

$\begin{array}{llll}\begin{array}{l}\text { Minimum } \\ \text { value }\end{array} & \begin{array}{l}\text { Maximum } \\ \text { value }\end{array} & \text { Mean } & \begin{array}{l}\text { Standard } \\ \text { Deviation }\end{array}\end{array}$


1 Total Assets Turnover

0.04

1.61

0.69

0.34

2 Receivables Turnover

0.34

16.82

5.32

4.12

3 Inventory Turnover

0.39

12.14

3.01

2.32

$4 \quad$ Operating Ratio

67.62

1106.02

136.33

176.31

H01: There is no statistically significant effect of applied contemporary MAPs on the rate of

Total Assets Turnover in the Jordanian industrial corporations.

Table 9 : Effect of MAPs on Total Assets Turnover $(n=52)$

\begin{tabular}{|c|c|c|c|c|c|c|c|}
\hline Independent variable & $\begin{array}{c}t \\
\text { value }\end{array}$ & $\begin{array}{l}t \\
\text { sig }\end{array}$ & Beta & $\mathbf{R}$ & $\mathbf{R}^{2}$ & $\begin{array}{l}F \\
\text { value }\end{array}$ & $\begin{array}{l}F \\
\text { sig }\end{array}$ \\
\hline Target Costing & 0.137 & 0.892 & 0.018 & & & & \\
\hline Just-in-Time Manufacturing & 0.258 & 0.797 & 0.037 & & & & \\
\hline Activity Based Costing & 0.180 & 0.858 & 0.024 & 0.389 & 0.151 & 1.852 & 0.119 \\
\hline Balanced Scorecard & 2.085 & 0.042 & 0.296 & & & & \\
\hline Kaizen Costing & 2.493 & 0.016 & 0.379 & & & & \\
\hline
\end{tabular}

\section{* Dependent variable: Total Assets Turnover}

Results of Testing H01

Table (9) shows that: There are no statistically significant effect at significant level $(\alpha \leq 0.05)$ of modern administrative accounting methods on Total Assets Turnover in Jordanian industrial corporations, where $F$ value reached $(1.852)$ by statistically significant $(0.119)$, (R) value reached (0.389) and $\left(\mathrm{R}^{2}\right)$ value reached $(0.151)$.

H02: There is no statistically significant effect of applied contemporary MAPs on the rate of Receivables Turnover in the Jordanian industrial corporations.

Table 10. Effect of MAPs on Receivables Turnover $(n=52)$

\begin{tabular}{lllllllll} 
Independent variable & $t$ & value & $t$ & Beta & $\mathbf{R}$ & $\mathbf{R}^{2}$ & $F$ & \\
& & & & & & & \\
& & & & value & sig \\
\hline
\end{tabular}




\begin{tabular}{|c|c|c|c|c|c|c|c|}
\hline Target Costing & 0.190 & 0.850 & 0.026 & & & & \\
\hline Just in Time Manufacturing & 0.128 & 0.899 & 0.019 & & & & \\
\hline Activity Based Costing & 1.062 & 0.293 & 0.148 & 0.324 & 0.105 & 1.216 & 0.315 \\
\hline Balanced Scorecard & 0.137 & 0.892 & 0.020 & & & & \\
\hline Kizen Costing & 1.822 & 0.072 & 0.284 & & & & \\
\hline
\end{tabular}

\section{* Dependent variable: Receivables Turnover}

Results of Testing $\mathrm{H} 02$

Table (10) shows that: There are no statistically significant effect at significant level $(\alpha \leq 0.05)$ of MAPs on Receivables Turnover in Jordanian industrial corporations, where $F$ value reached $(1.216)$ by statistically significant $(0.315),(R)$ value reached $(0.324)$ and $\left(R^{2}\right)$ value reached (0.105).

H03: There is no statistically significant effect of applied contemporary MAPs on the rate of Inventory Turnover in the Jordanian industrial corporations.

Table 11. Effect of MAPs on Inventory Turnover $(n=52)$

\begin{tabular}{llllllll}
\hline Independent variable & $\boldsymbol{t}$ value & $\boldsymbol{t}$ & Beta & $\mathbf{R}$ & $\mathbf{R}^{2}$ & $\boldsymbol{F}$ & $\boldsymbol{F}$ \\
& & sig & & & & value & sig \\
\hline Target Costing & 0.019 & 0.985 & 0.002 & & & \\
Just in Time Manufacturing & 0.331 & 0.742 & 0.046 & & & & \\
Activity Based Costing & 0.835 & 0.407 & 0.109 & 0.466 & 0.218 & 2.892 & \\
Balanced Scorecard & 2.546 & 0.014 & 0.347 & & & & \\
Kizen Costing & 2.553 & 0.014 & 0.372 & & & & \\
\hline
\end{tabular}

\section{* Dependent variable: Inventory Turnover}

Results of Testing H03

Table (11) shows that: There are a statistically significant effect at significant level $(\alpha \leq 0.05)$ of MAPs on Inventory Turnover in Jordanian industrial corporations, where $F$ value reached (2.892) by statistically significant $(0.022)$, $(\mathrm{R})$ value reached $(0.466)$ and $\left(\mathrm{R}^{2}\right)$ value reached 
(0.218).

H04: There is no statistically significant effect of applied contemporary MAPs on Operating Ratio in the Jordanian industrial corporations.

Table 12. Effect of MAPs on Operating Ratio $(n=52)$

\begin{tabular}{lcccccccc}
\hline Independent variable & $\boldsymbol{t}$ value & $\boldsymbol{t}$ & Beta & $\mathbf{R}$ & $\mathbf{R}^{2}$ & $\boldsymbol{F}$ & $\boldsymbol{F}$ \\
& & sig & & & & value & sig \\
\hline Target Costing & 0.114 & 0.910 & 0.016 & & & \\
Just in Time Manufacturing & 0.744 & 0.460 & 0.110 & & & \\
Activity Based Costing & 0.229 & 0.820 & 0.032 & 0.322 & 0.104 & 1.207 & 0.319 \\
Balanced Scorecard & 2.356 & 0.022 & 0.343 & & & & \\
Kizen Costing & 1.476 & 0.146 & 0.230 & & & & \\
\hline
\end{tabular}

\section{* Dependent variable: Operating Ratio}

Results of Testing H04

Table (12) shows that: There are no statistically significant effect at significant level $(\alpha \leq 0.05)$ of MAPs on Operating Ratio in Jordanian industrial corporations, where $F$ value reached (1.207) by statistically significant $(0.319)$, $(\mathrm{R})$ value reached $(0.322)$ and $\left(\mathrm{R}^{2}\right)$ value reached (0.104).

\section{Results and Recommendations}

\subsection{Results}

This study designed to examine the extent use and utilization of contemporary MAPs in Jordanian industrial corporations, and to reveal if there are any significant effects of MAPs on operational performance. Based on the results of statistical analysis and hypothesis testing, results can be summarized as follows:

- Difference were remarkable in utilization of contemporary MAPs. According to the opinions of accountants responding to the questionnaire, most of Jordanian industrial corporations engaged in utilizing contemporary MAPs at different levels, with an overall medium mean value (2.93).

- The findings produce some original results on the use of contemporary MAPs by the Jordanian industrial corporations; in general, industrial corporations have wide adoption of MAPs, such as Kaizen costing, Just-in-time manufacturing and Target costing. 
- MAPs have rather a limited extent use or inadequate implementation. Furthermore, results show that the implementation rate of $\mathrm{ABC}$ and $\mathrm{BSC}$ was the lowest among all five areas of contemporary MAPs examined

- Results of descriptive analysis of the study sample responses shows that Kaizen costing domain was the highest domain utilized with a mean value (3.68), and the least domain used is BSC with mean value of (2.30).

- There are no statically effects of contemporary MAPs on operational performance, with $F$ value of (1.852) with statistically significant (0.119) for the domain Total Assets Turnover and $F$ value of (0.315) with statistically significant (0.324) for the domain Receivables Turnover and $F$ value of (1.207) with statistically significant (0.319) for the domain Operating ratio.

- There is a statistically significant effect of MAPs on operational performance, with $F$ value of (2.892) with statistically significant $(0.022)$ for the domain Inventory Turnover.

- Results reveal some supports for the hypothesized proposition that there is significance effect of applied MAPs on operational performance. None the less, study results of data analyzed showed that there are no effects observed of applied contemporary MAPs on operational performance of industrial corporations except of inventory turnover indicator.

\subsection{Recommendations}

Based on the aforementioned results and in order to provide references in light of previous findings, the study recommends the following:

- Corporate managers and decision-makers should reconsider the mechanism of contemporary MAPs applied in the industrial corporations.

- Reaffirmation to the industrial corporation's administration to apply and utilize the various contemporary MAPs to achieve the advantages and benefits of using these practices.

- Increase the awareness of administrations in industrial corporations to the importance of applying the various contemporary MAPs and its roles in improving operational performance and increasing profitability.

- Activate the role of various contemporary MAPs used as an information system contribution in serving the management's objectives.

- Develop the accounting and administrative systems in industrial corporations to be more compatible and suitable with the development of modern manufacturing systems.

- The benefits of each practice used should be examined and cost benefit analysis should be made for each practice applied and realize the benefits obtained.

- Need to ensure that there is an appropriate administrative structure and qualified staff before applying any of contemporary MAPs, furthermore the administrative structure is the most important factor to realize success in application of these practices.

- Necessity of continuing and enhancing the adoption of MAPs in Jordanian industrial 
corporations, and keeping abreast of the latest developments in this field and select what is appropriate for the company.

- Overall, the researcher emphasis the necessity to improve the awareness of applying various MAPs and its effect on operational performance in Jordanian industrial corporations, moreover, further researches could consider additional practices and operational variables that may reveal the important roles and relationship between MAPs and operational performance.

- Conducting further similar studies in future involving other sectors such as service and commercial sectors.

\section{References}

Ahmad, K. (2017) The Implementation of Management Accounting Practices and its Relationship with Performance in Small and Medium Enterprises. International Review of Management and Marketing, 7(1),342-353.

Al-Khalil., M.A. (2012). Applying Modern Techniques of Managerial Accounting in The Jordanian Industrial Public Shareholding Companies. Master degree Paper, Middle East University, Amman-Jordan.

Amman Stock Exchange. (2017). Retrieved from http://www.ase.com.jo/ar/equities.

Andrei, G. F. (2017). Critical Aspects regarding the Implementation of Managerial Accounting Systems. “Ovidius” University Annals, Economic Sciences Series, Volume XVII(1),491-496.

Ansari, S. L., Bell, J. E., \& the CAM-1 Target Cost Core Group. (2010). Target Costing: The next frontier in Strategic Cost Management. Burr Ridge, IL, Irwin McGraw Hill Companies.

Argyris, C., \& Kaplan, R. (1994). Implementing New Knowledge: The Case of Activity-Based Costing. Accounting Horizons, 8(3), 83-105.

Ashfaq, K.,Younas, S., Usman, M., \& Hanif, Z. (2014). Traditional Vs. Contemporary Management Accounting Practices and its Role and Usage across Business Life Cycle Stages: Evidence from Pakistani Financial Sector. International Journal of Academic Research in Accounting, Finance and Management Sciences, 14(4), 104-125.

Bahar, M. (2012). Conceptual Framework for Launching and Implementing Target Costing in Automotive Industry. International Journal of Research in IT \& Management, 2(6), 21-33.

Bhattacharyya., Dearder., \& John. (1996). Accounting for Management: Text and Cases, Kaykay Printers, Delhi.

Cobb, I. (1992). JIT and the Management Accountant. Management Accounting, 70(20), London.

Cooper, R. \& Kaplan, R. (1988). Measure Costs Right: Make the Right Decisions. Harvard Business Review, Sep.Oct., 96-103.

Cuzdrioreana, D. (2017).The Use of Management Accounting Practices by Romanian Small and Medium-Sized Enterprises: A Field Study. Accounting and Management Information 
Systems, 16(2), 291-312.

Dodds, D. (1992). Making it Better and Better. CMA Magazine, Feb, pp 16-21.

Eccles, R, G., (1991) Performance Measurement Manifesto. Hurra Business review, 69(1).

Garison, R., Noreen, E., \& Brewer, P. (2012). Managerial Accounting, 14Th ed, McGraw-Hill/Irwin, a business unit of The McGraw-Hill Companies, Inc., 1221 Avenue of the Americas, New York.

Heitger, D.L., Maryanne M. M., \& Hansen D. R. (2008). Fundamental Cornerstone of Managerial Accounting, Thomason South-western,Thomson Corporation,Canada.

Hilton, R. W. (2002). Managerial Accounting, 5th ed, The McGraw-Hill Companies, Inc., 1221 Avenue of the Americas, New York.

Horngren, C. T., FOSTER, G., DATAR S, M., RAJAN, M., \& ITTNER, C. (2009). Cost Accounting : A Managerial Emphasis, 13th ed, NJ, Pearson Prentice Hall, xxvii, 870.

Howell, R. (1994). Implementing Target Costing. Management Accounting Guideline, 3(2), 26-28. Published by Institute of Management Accountants10 Paragon Drive Montvale, NJ 07645www.imanet.org, IMA Publication.

Kaplan, R.S., \& Atkinson, A. (1998). Advanced Management Accounting, ed 3, prentice-Hall. Inc, New Jersey.

Kaneko, J., \& Nojiri, W. (2008).The logistics of just-in-time between parts suppliers and car assemblers in Japan. Journal of Transport Geography, 16(3), 155-173. https://doi.org/10.1016/j.jtrangeo.2007.06.001

Miller Kent D., \& Bromiley Philip. (1990). Strategic Risk and performance an analysis of Alternative Risk Measures. Academy Management Journal 33(4), 756-779. https://doi.org/10.2307/256289

Moscove, S. A., \& Wright, A. A. (1990). Cost Accounting With Managerial Applications, 6th ed, Houghton,Mifflin company,USA.

Robins., Jemes, \& Wiersema Margrethe F. (1995).A Resource Based Approach to Multi business Firry Empirical Analysis of Portfolio Interrelationship and corporate Financial Performance. Strategic Management Journal, 16(4), 277- 299.

Simon, C., Marko, H., \& Z, Maja. (2005). A Cross-Industry Comparative Analysis of Strategic Management Accounting Techniques Application: Evidence from Slovenia. Sixth International Conference on Enterprise in Transition, 1029-1042.

Topor, D. L., Putan, A., \& Capusneanu, S. (2011). The Role of Management Accounting in providing Information for Making Decision within an Entity. International Journal of Academic Research in Accounting, Finance and Management Sciences, 1(1), 56-66.

Waldron, M. (2007). Today's Management Accounting Techniques in NZ Businesses, Chartered Accountants journal, Feb, 32-34. 